\title{
First record of the invasive Arctodiaptomus dorsalis (Marsh, 1907) (Copepoda:Calanoida:Diaptomidae) in Lake Lanao (Mindanao Island, Philippines)
}

\author{
Ephrime B. Metillo ${ }^{1}$, Alyza M. Masorong ${ }^{1}$, Sittie Aisah N. Macabangkit ${ }^{1}$, \\ Jill Rosette U. Licayan ${ }^{1}$, Dino T. Tordesillas ${ }^{2,5}, \mathcal{E}$ Rey Donne S. Papa ${ }^{2,3,4 *}$ \\ ${ }^{1}$ Department of Biological Sciences, College of Science and Mathematics \\ Mindanao State University-Iligan Institute of Technology, Iligan City \\ ${ }^{2}$ The Graduate School, ${ }^{3}$ Research Center for the Natural and Applied Sciences \\ ${ }^{4}$ Department of Biological Sciences, University of Santo Tomas \\ España Boulevard, 1015 Manila \\ ${ }^{5}$ Biology Department, St. Paul University-Quezon City, PHILIPPINES
}

\begin{abstract}
Arctodiaptomus dorsalis, originally described to be distributed within the Americas, has been documented to occupy a significant number of freshwater lakes in the Philippines. This paper reports the first record of $A$. dorsalis in Lake Lanao, an ancient lake located in the island of Mindanao. Based on its very high abundance, and positive correlation between the total body length of females with lake dissolved nitrates, phosphates and chlorophyll a concentration, A. dorsalis has clearly established itself in the lake ecosystem and has benefitted in the steady increase in the lake's nutrient load. Lake Lanao's endemic Tropodiaptomus gigantoviger may be considered as another calanoid species to be displaced by A. dorsalis given that a thorough examination of plankton samples collected from Lake Lanao have not yielded individuals of $T$. gigantoviger.
\end{abstract}

Keywords: Invasive species, Copepods, Tropical Limnology, Non-Indigenous Zooplankton

\section{INTRODUCTION}

One of the ancient lakes on Earth [1], Lake Lanao (8”00’N, 123”50’E) is an oligotrophic, freshwater lake [2] located on the northwest region of Mindanao. With a recorded maximum depth of $112 \mathrm{~m}$ and an area of 35,600 ha, it is one of the deepest and largest lakes in the country [3]. The

*To whom correspondence should be addressed rspapa@mnl.ust.edu.ph / reypaps@yahoo.com lake and its surrounding watershed have been declared as a National Park and Reserve [2], and a priority area for conservation and research [4]. Lake Lanao has been the focus of studies by William Lewis, publishing data on its abiotic properties [5] and its zooplankton community [6], which was noted to be dominated by Chaoborus larvae. It is inhabited by at least 18 endemic cyprinid fish species [3] and Tropodiaptomus gigantoviger, an endemic calanoid copepod [6]. 
Members of the genus Tropodiaptomus have also been documented to be present in Laguna de Bay [7], Lake Buhi and Lake Taal [7-8] but have not been recorded from these sites in more recent studies [9]. Another endemic calanoid species, Filipinodiaptomus insulanus, which was originally recorded from Laguna de Bay [10], Lake Danao in Leyte [11], and Lake Paoay [12] has suffered the same disappearance as that of Tropodiaptomus. The absence of these endemic species in more current literature has been tied to the observation of Arctodiaptomus dorsalis in lakes previously inhabited by Tropodiaptomus and F. insulanus [9].

A species originally described with a range extending from the southern United States to Central America and northern South America, A. dorsalis was first reported in Philippine waters in 1991 (M. Directo, unpublished report to International Zooplankton Course, Ghent University, 1993). Its occurrence in Laguna de Bay, Lake Mainit, and Lake Sebu was reported in 2001 [11] and its invasion of 18 lakes in the country was published in 2012 [9]. After more than two decades, it has spread to other inland waters of the country, a situation that may eventually lead to the establishment of $A$. dorsalis in other parts of Asia [9]. Though more recent papers think this is highly unlikely [19], the threat of invasion of microscopic organisms has always been very difficult to monitor and therefore necessitates a more vigilant approach by concerned scientists and government agencies.

This paper presents the first record of $A$. dorsalis in Lake Lanao and offers an insight on how this invasive species may have taken over the lake and its probable effect on the endemic T. gigantoviger.

\section{EXPERIMENTAL}

Samples were collected from opposite sides of the lake (Fig. 1). Four transects were established in Marawi City in the north and three in Bayang, Lanao del Sur in the south. Collection points were set up within each transect, originating from the shoreline.

Sampling was done once a month during the inter-monsoon (May) and southwest monsoon (August to September) seasons of 2013 by vertical towing of $80 \mu \mathrm{m}$ conical plankton net; with a mouth diameter of $234 \mathrm{~cm}$. Samples were then preserved in 5\% formalin. Water samples were also obtained for the determination of selected physico-chemical factors such as dissolved phosphate, nitrates, and Chlorophyll a. Water samples were brought to the MSU-IIT Chemistry Department for analyses. Other physico-chemical parameters such as water temperature, depth, and transparency were measured on site using a mercury thermometer and Secchi disk. The $\mathrm{pH}$ and dissolved oxygen values were determined using portable $\mathrm{pH}$ and D.O. meters, respectively.

Collected plankton samples were then filtered through $20 \mu \mathrm{m}$ mesh sieves, and stained with Rose Bengal dissolved in 5\% formalin in the

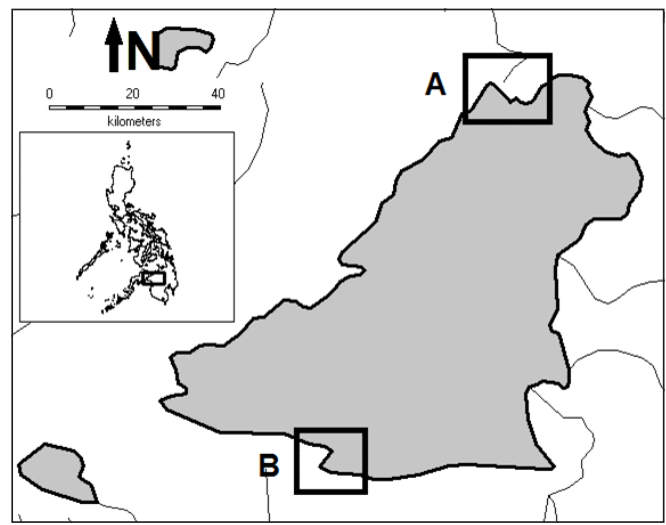

Figure 1. Map of Lake Lanao indicating the sampling sites. A - Marawi City, B - Bayang 
laboratory. Samples were divided into two equal halves. One was used for identification, sorting and measuring while the other half was used for density determination [9]. The first halves of the samples were used to measure the density of the samples using a Sedgewick Rafter counting chamber. Three trials were done on each sample per month and per site. Life stages counted were the Nauplii stage, Copepodite, Adult Male, and Female. Density determination was calculated using the following equation:

$$
D=T C / \pi r^{2} h
$$

where $\mathrm{D}$ is density, TC is total count, $r$ is the radius of the plankton net and $h$ is the distance of the tow. Of the sorted specimens, micrographs were taken and analyzed using ImageJ 1.48 (Freeware downloaded from http:// imagej.nih.gov/ij/) to take morphometric data of adult females which were correlated against measurements of Secchi disk transparency (SDT), dissolved phosphates (DP) and nitrites (DN), and Chorophyll a (Chla) using PAleontological STatistics (PAST) Version 3.02 (Freeware downloaded from http://folk.uio.no/ ohammer/past/).

\section{Results AND Discussion}

Arctodiaptomus dorsalis was collected from all seven transects during the inter-monsoon and southwest monsoon seasons. Juveniles form the majority of the samples (Fig. 2), suggesting that reproduction is continuous [13]. As an $r$ strategist, $A$. dorsalis is capable of producing a large number of fast developing eggs, with juveniles developing quickly as well when food is not a limiting factor [14].

Statistical analyses of correlation of total length (TL) of adult females yielded a negative correlation with SDT, but positive relationships with DP, DN and Chla (Table 1). Increase in egg production has been positively correlated to an increase in TL in Eudiaptomus dreischi [15],

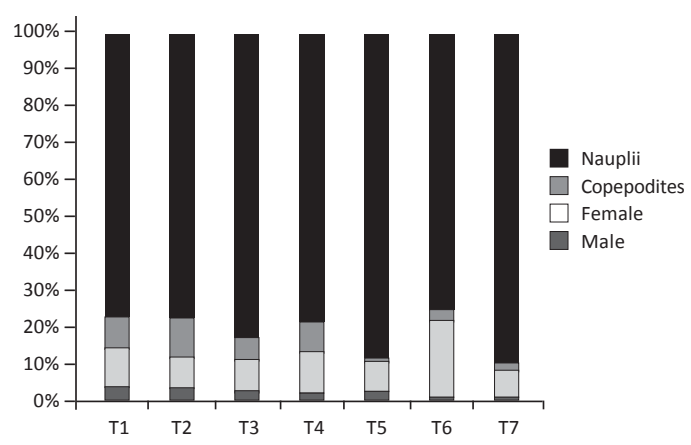

Figure 2. Relative abundance of $A$. dorsalis collected during the study from the all the seven transects

Table 1. Pearson- $r$ and $P$ values for correlation of female $A$. dorsalis total length (TL) with SDT, DP, DN and Chla

\begin{tabular}{l|c|c}
\hline & $r$ & $P$ \\
\hline Secchi Disc Transparency & -0.61756 & 0.13949 \\
\hline Dissolved Phosphorous & 0.28962 & 0.52869 \\
\hline Dissolved Nitrates & 0.50482 & 0.24788 \\
\hline Chlorophyll a & 0.41878 & 0.34972 \\
\hline
\end{tabular}

Pseudocalanus [16], and Eurytemora affinis [17], as well as an increase in Chla [16, 17]. These factors could provide a probable explanation on the reproductive success of $A$. dorsalis in Lake Lanao as the lake is known to have increased nutrient levels through the years due to increasing eutrophication. Throughout the sampling period, it was evident that microalgal blooms were present in the sampling sites.

The clear dominance of $A$. dorsalis over other calanoids in lakes where it has established itself [9] may have already occurred in Lake Lanao where the endemic $T$. gigantoviger was previously recorded $[7,8,18]$. If this was the case, T. gigantoviger will be next in the list of Philippine calanoid species to be replaced by $A$. dorsalis, together with $T$. vicinus, Pseudodiaptomus brehmi, P. nostradamus, and Filipinodiaptomus insulanus [9]. According to Havens \& Beaver [19], A. dorsalis has a 
tendency to fill niches vacated by other zooplankton species, especially if eutrophication and predation are taken into consideration.

The exact reason behind how $A$. dorsalis came to the Philippines is still unknown but there is a probable correlation with the spread of aquaculture, particularly, of introduced species [14]. This correlation is yet to be established in the Philippines, hence, further research should be done in the future.

In the Americas, $A$. dorsalis was documented to be expanding its range, relating A. dorsalis' spread to aquaculture and eutrophication [14]. Lake Lanao, with its increased anthropogenic activities, introduction of exotic species and increased concentration of organic waste [20], now has characteristics that are favorable for the establishment of $A$. dorsalis. These factors may also have led to a decrease in zooplankton diversity [20], lessening predation pressure by cyclopoids on A. dorsalis [21]. And with the proliferation of $A$. dorsalis, there is an increased competition for prey items with cyclopoids. Therefore, as cyclopoid populations decrease due to the lessening of their food items by calanoids, the latter increase in number because of lessening predation by cyclopoids, and the cycle goes on, giving calanoids a clear advantage.

This record of A. dorsalis in another Philippine lake shows the extent of invasion by this calanoid, particularly in the island of Mindanao. Increased aquaculture, eutrophication, introduction of exotic species are probable causes for the proliferation of A. dorsalis but further studies should be conducted to confirm this correlation. As it is, there seems to be "pockets" of invasion by A. dorsalis in the Philippines, which seem to be related to the degree of aquaculture intensity in the country with Laguna de Bay (southern Tagalog region), Lake Buhi (Bicol) and Lake Sebu (western
Mindanao) being centers of the invasion [9]. Other zooplankton should also be considered and how this invasion has impacted the community diversity and dynamics of the lake. The status of Lake Lanao itself should also be prioritized for future research efforts. As one of the major lakes in the country, the lake ecosystem's impact on biodiversity is as significant as its importance to the people of Lanao.

\section{AcKNowledgment}

The researchers wish to thank the Department of Chemistry of the Mindanao State University - Iligan Institute of Technology for their assistance in chemical analyses. Dr. R.D.S. Papa was supported by funding from the Research Center for the Natural and Applied Sciences (RCNAS) of the University of Santo Tomas for the project "Establishing a Zooplankton Reference Collection in the University of Santo Tomas" while Mr. DT Tordesillas was supported by the Department of Science and Technology Acceleration of Science and Technology Human Resource and Development Program (DOSTASTHRDP). R.D.S. Papa and E.B. Metillo were supported by the Asian CORE-COMSEA Project of the Japan Society for the Promotion of Science (JSPS).

\section{REFERENCES}

[1] Naga P. The Lake Lanao Issue. 2004 (Retrieved from World Lakes Website: http://www.world lakes.org/uploads/Lake_Lanao_Issue_ WorldLakes.pdf).

[2] Alonzo-Pasicolan S, Magsalay P. Lake Lanao (n.d.). (Retrieved from ASEAN Regional Centre for Biodiversity Conservation: http:// www.arcbc.org.ph/wetlands/philippines/ phl_laklanao.html).

[3] Ismail GB, Sampson DB, Noakes DLG. The status of Lake Lanao endemic cyprinids (Puntius species) and their conservation. Environ. Biol. Fishes. 2013; 97(4):1-10. 
[4] Ong P, Afuang L, Rosell-Ambal R (Eds.). Philippine Biodiversity Conservation Priorities: A Second Iteration of the National Biodiversity Strategy and Action Plan. (Quezon City: Deparment of Environment and Natural Resources-Protected Areas and Wildlife Bureau, Conservation International Philippines, Biodiversity Conservation Program-University of the Philippines Center for Integrative and Development Studies, and Foundation for Foundation for Philippine Environment, Quezon City, Philippines, 2002).

[5] Lewis Jr W. The thermal regime of Lake Lanao (Philippines) and its theoretical implications for tropical lakes. Limnol. Oceanogr. 1973; 18(2):200-217.

[6] Lewis Jr W. Primary production in the plankton community of a tropical lake. Ecol. Monogr. 1974; 22(4):377-409.

[7] Mamaril Sr A. Zooplankton diversity in Philippine lakes. In: Santiago C, Cuvin-Aralar M, \& Basiao Z (Eds.) Conservation and Ecological Management of Philippine Lakes in Relation to Fisheries and Aquaculture, pp. 81-93 (Southeast Asian Fisheries Development Center, Aquaculture Department, Iloilo, Philippines; Philippine Council for Aquatic and Marine Research and Development, Los Baños, Laguna, Philippines; and Bureau of Fisheries and Aquatic Resources, Quezon City, Philippines, 2001).

[8] Mamaril Sr. A. Philippine Zooplankton. In: Guide to Philippine Flora and Fauna (Vol. 7), pp. 178). (National Resources Management Center and University of the Philippines, Diliman, 1986).

[9] Papa RS, Li H, Tordesillas DT, Han B, Dumont HJ. Massive invasion of Arctodiaptomus dorsalis (Copepoda, Calanoida, Diaptomidae) in Philippine lakes: a threat to Asian zooplankton biodiversity? Biol. Invasions. 2012; 14:2471-2478.

[10] Mamaril Sr. A, Fernando, C. Freshwater zooplankton of the Philippines (Rotifera, Cladocera, and Copepoda). Nat. Appl. Sci. Bull, 1978; 30(4):109-221.

[11] Tuyor J, Baay M. Contribution to the knowledge of freshwater copepods of the Philippines. Asia Life Sci. Philipp. Asian Int. J. Life Sci. 2001; 10(1):45-54.
[12] Aquino MR, Cho C, Cruz MA, Saguitguit MA, Papa RD. Zooplankton composition and diversity in Paoay Lake, Luzon Is., Philippines. Philipp. J. Sci. 2008; 137(2):169-177.

[13] Papa RD, Zafaralla M, Eckmann R. Spatiotemporal variation of the zooplankton community in a tropical caldera lake with intensive aquaculture (Lake Taal, Philippines). Hydrobiologia 2011; 664(1):119-133.

[14] Reid JW. Arctodiaptomus dorsalis (Marsh): A case history of copepod dispersal. Banisteria 2007; 30:3-18.

[15] McLaren IA. Some relationships between temperature and egg size, body size, development, rate, and fecundity of the copepod Pseudocalanus. Limnol. Oceanogr. 1965; 10:528-538.

[16] Bozkurt A Can MF. Seasonal variations in body length and fecundity of 2 copepod species: Thermocyclops crassus (Fischer, 1853) and Eudiaptomus drieschi (Poppe \& Mrázek, 1895). Turk J Zool. 2014; 38(2):222-228.

[17] Lloyd SS, Elliott DT, Roman MR. Egg production by the copepod, Eurytemora affinis, in Chesapeake Bay turbidity maximum regions. J. Plankton Res. 2013; 35(2):299-308.

[18] Brehm V. Uber die Diaptomiden und Pseudodiaptomiden der Zwischenregion Wallacea. Internationale Revue der gesamten Hydrobiologie und Hydrographie 1942; 42:264268.

[19] Havens K, Beaver J. Predicting impacts of an invading copepod by ecological assessment in the animal's native range. Inland Waters 2013; 4:49-56.

[20] Tuddao Jr VB. Retrospective Risk Assessment Study of Lake Lanao Aquatic Environment. (n.d.). from Philippine Clearing House Mechanism: (http:/ /www.chm.ph/index.php?option=com_docman \&task=doc_download\&gid=219\&ltemid=74).

[21] Anneville O, Molinero J, Souissi S, Balvay G, Gerdeau D. Long-term changes in the copepod community of Lake Geneva. J. Plankton Res. 2007; 29(Suppl. 1):i49-i59. 